\title{
An Assessment of the Remodeling of Bifurca- tions in Hazel (Corylus avellana L.) in Response to Bracing, Drilling, and Splitting
}

\author{
Duncan Slater and A. Roland Ennos
}

\begin{abstract}
The ability of trees to remodel their woody structure after injury or strain to outer tissues greatly assists in their survival; however, this remodeling process is complex because it is influenced by many factors. The speed and extent of remodeling of branch junctions in trees around a mechanical flaw, such as included bark, will dictate to what extent and for how long the junction is mechanically weakened.

In this study, 100 normally formed bifurcations in semi-mature hazel (Corylus avellana L.) were artificially modified by being rodbraced, drilled through the apex or split, and then left to grow in situ. Two further groups were identified as controls: 120 normally formed bifurcations and 70 bark-included bifurcations. After two to four years, these bifurcations were harvested and underwent tests of their bending strength. The bifurcations rigidly braced over three growing seasons developed adverse taper in their branches and had only $70.5 \%$ of the bending strength of the normally formed bifurcations. Bifurcations with the central $20 \%$ of the xylem drilled out of them were capable of recovering fully from this defect; in contrast, split bifurcations were found to be highly vulnerable to failure during wind-loading events.

This study concludes that a bifurcation may be considered compromised in its bending strength if its apex is compromised, but that semi-mature bifurcations in hazel do exhibit a good ability to remodel after injury. The role of thigmomorphogenesis in this remodeling process is assessed with reference to the rod-braced specimens that suffered no significant mechanical perturbation at their apices.

Key Words. Bark Inclusion; Bifurcation; Biomechanics; Bracing; Corylus avellana L.; England; Hazel; Lancashire; Remodeling; Thigmomorphogenesis; Tree Crotch; Tree Fork.
\end{abstract}

In response to mechanical perturbation, plants undergo the process of thigmomorphogenesis, whereby plant growth adapts in response to strains experienced by the plant's tissues (Jaffe and Forbes 1993; Coutand 2010; Telewski 2012). Mechanosensing and subsequent adaption of plant growth is well-reported for plant height and form, the modification of the shapes of leaves, peduncles, petioles, and the selective thickening of the branches and stems of plants (Whitehead 1963; Jaffe 1973; Grace 1977; Biro et al. 1980; Braam and Davis 1990; Farnsworth and Niklas 1995; Pruyn et al. 2000; Telewski 2006). It can be surmised that the majority of plant structures are likely to have this ability to respond to strain, including the junctions of the aerial parts of woody plants. Indeed, Jungnikl et al. (2009) found substantial adaptation to the tissues of junctions in Pinus using wide-angled X-ray scattering to determine micro-fibril angle differences and CT scanning to uncover wood density differences. These analyses showed substantial modifications to the scanned branch junctions where stresses acting on these junctions would be heightened.

Thigmomorphogenesis is triggered by the strain experienced by meristematic cells (Philipson et al. 1971; Telewski 2006; Monshausen and Haswell 2013). In trees and other woody plants, thigmomorphogenesis can be a local phenomenon to parts of their structure, with secondary thickening occurring fastest where the highest mechanical strains are experienced (Steucek and Kellogg 1972; Mattheck and Linnard 1998). It is important, however, to note that remodeling within woody plants may be for a range of functions and that mechanical strain is only one potential influence upon how a plant's structure develops. In woody plants, sapwood serves 
a range of functions (Gartner 1995; Badel et al. 2015), not solely as the structural support of the plant's stems and branches, and remodeling responses to a defect formed in the sapwood of a woody plant are potentially complex.

Junctions in the aerial parts of trees are considered to be potential failure points by arborists (Shigo 1991; Lonsdale 1999), although scientific studies of the bending strength of such junctions have been restricted to static testing for practical reasons (Gilman 2003; Kane et al. 2008; Slater and Ennos 2013). Static testing, in contrast to the dynamic movement of plants under natural loading, involves the application of a fixed load or a fixed rate of displacement in order to assess the strength of a component of a plant's structure, and results from such tests need careful interpretation when related back to real world performance of such components. A greater understanding of the biomechanical behavior of such junctions and their ability to remodel around a defect would assist in tree management and the prediction of tree failures.

An anatomical model for junctions in trees has been outlined by Slater et al. (2014) based on visual observations of the grain patterns found at junctions of 20 tree and shrub species. This model was supported by CT scanning of bifurcations in common hazel (Corylus avellana L.) to observe the orientation of vessels, rays, and fibers at the bifurcation apex. This anatomical model emphasizes the importance of the xylem lying under the branch bark ridge as the main contributor to the bending strength of bifurcations, with the xylem tissues in this location typically being denser and exhibiting fewer vessels of a smaller diameter and shorter length when compared with adjacent xylem in the stem (Slater et al. 2014).

Slater et al. (2014) also describe how the wood grain pattern formed at the bifurcation apex results in some degree of interlocking of the grain such that wood fibers need to be stretched axially or pulled out of the tissue matrix along their length in order to break the bifurcation apart (Figure 1). In mature limbs of many temperate tree species, whorled grain can be found at the apex of junctions (Lev-Yadun and Aloni 1990) as a subsequent development of this initial interlocking pattern (Figure 1B).

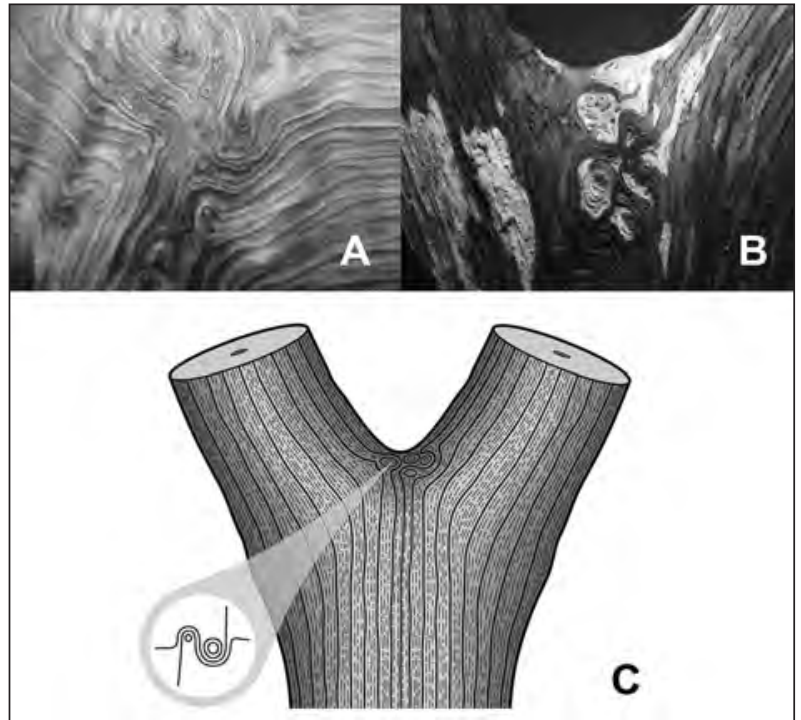

Figure 1. A) Interlocking wood grain pattern at the apex of a junction of common ash (Fraxinus excelsior L.), as exposed by debarking. B) Wood grain pattern at the apex of a bifurcation of common oak (Quercus robur L.) incorporating whorled grain. C) Diagrammatic representation of interlocking wood grain in a normally-formed bifurcation in a woody plant, based on the anatomical model of Slater et al. (2014) with inset displaying a basic interlocking pattern of wood grain incorporating whorled grain.

It is a common occurrence, however, that bark is included in such bifurcations during their development. These bark-included bifurcations are weaker under static loading than normally-formed bifurcations (Kane et al. 2008; Slater and Ennos, 2015). In addition, if the apex of a bifurcation consists of bark then that bark could act as a barrier to the future development of a normally-formed connection consisting of this denser tortuous sapwood.

In this study, researchers investigated the ability of bifurcations in hazel trees to remodel around artificially-induced defects. Previous work by Steucek and Kellogg (1972) in Norway spruce [Picea abies (L.) H. Karst] identified that trees remodel around such defects and discontinuities partially due to heightened stress levels at the location of the induced defect and partly due to the partial girdling that has occurred. Hazel was selected as the test subject for this study because the authors have carried out a series of complementary investigations into the anatomy and biomechanical properties of bifurcations in this species.

For this study, researchers investigated the loss of bending strength to these bifurcations caused by artificial wounding, comparing them to both 
normally formed and bark-included bifurcations grown in the same location. The three artificial defects studied were fixed-rod bracing of the two branches arising from bifurcations, the drilling out of the centrally-placed xylem at the apex of bifurcations, and the splitting of the apex of the bifurcation by pulling the two branches apart from each other.

It was hypothesized that the braced bifurcations, in the absence of them experiencing mechanical perturbation at their apices, would become weaker over time. It was further hypothesized that the drilled-out and split bifurcations would remodel around their artificially-induced defects, recovering their bending strength over time. Overall, the study aimed to provide evidence that mechanical loading was a key factor in the development of strength in these bifurcations, as well as identify the typical pattern of anatomical remodeling that occurred around these defect types.

\section{MATERIALS AND METHODS}

\section{Selection of Hazel Bifurcations}

A wind-exposed semi-mature shelterbelt consisting of a mix of broadleaved species that contained semi-mature hazel trees was selected for this experiment. The planted area was on the southern boundary of the campus of Myerscough College, Lancashire, England-grid reference: SD497399 (E 349711, N 439982). The trees in this shelterbelt were planted as three-year-old bare-rooted stock in 2004, making the hazel trees 13 years of age by the end of the study. All the bifurcations used for this experiment were formed less than two meters above ground level; this facilitated their modification by bracing, drilling, or splitting and ensured that the age and diameters of these bifurcations were similar.

Bifurcation selection was biased toward choosing bifurcations with a high diameter ratio $(80 \%+)$, as expressed by the percentage difference between the diameters of the thinner branch to the thicker branch arising from the bifurcation and as measured proximal to the bifurcation. Bifurcations were also selected so that both branches and the parent stem were ascending, all of them forming a relatively upright Y-shape, with no other significant branching to be found above or below $200 \mathrm{~mm}$ of the bifurcation apex. No more than three bifurcations were selected in the crown of any one hazel tree, which resulted in a random scattering of sample collecting along the $450 \mathrm{~m}$ length of the shelterbelt.

\section{Modifications to the Hazel Bifurcations}

In December 2010, an initial experiment was devised whereby 50 hazel bifurcations had the center of their apex drilled out and were left to develop over two to four years (Figure 2B). The drill bit size was selected for each bifurcation so that $20 \%$ of the width of the apical tissues were removed (Table 1) based on a measurement of the parent stem perpendicular to the bifurcation and just below the bulge formed by the branch bark ridge ( $P S_{2}$, Figure 3).

This drilling scheme matches carried out by Slater and Ennos (2013) on bifurcations of hazel that were tested to determine the contribution of the centrally-placed xylem to the bending

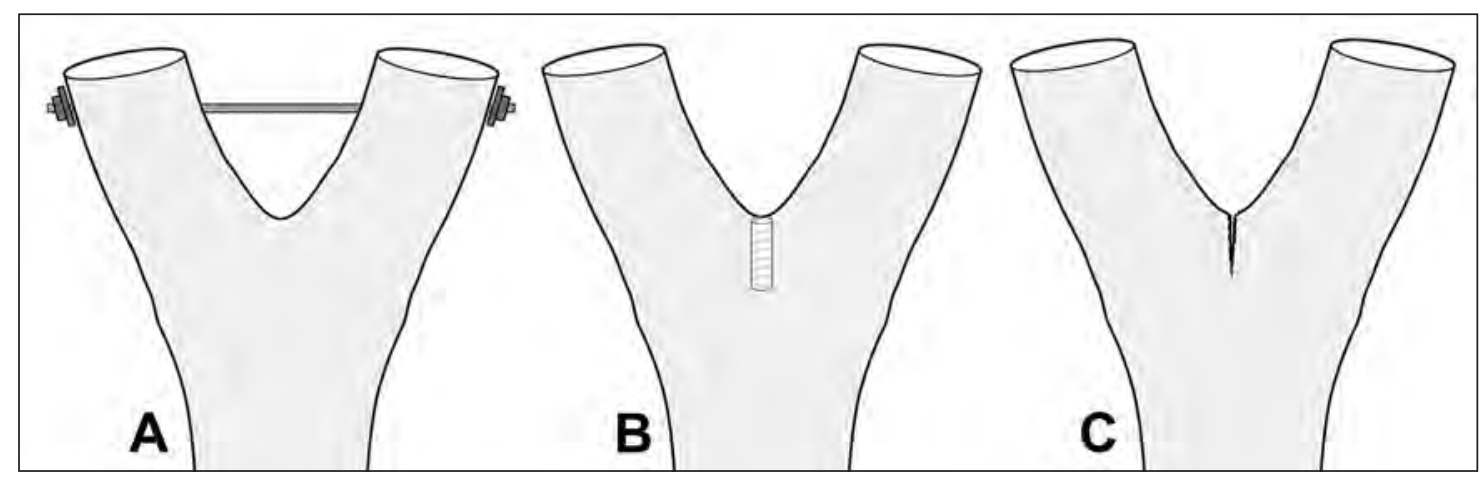

Figure 2. Artificially-modified bifurcations left to grow in situ for two to four years. A) Diagram of rod-bracing created in 25 hazel bifurcations. B) Diagram of drill hole created in 50 hazel bifurcations. C) Diagram of split created in 25 hazel bifurcations. 
strength of such bifurcations. However, in this experiment, these drilled bifurcations were left in situ, attached as a component of the tree, to assess whether and how the bifurcations would re-model around the induced defect of the drill hole. Each drill hole made was filled with silicon sealant that facilitated identification of these modified bifurcations when they were mechanically tested, and each was sprayed with a standard fluorescent forestry marking paint so that they could be identified and harvested at a later date. In addition, 50 normally formed bifurcations were also selected and spray painted within the same wooded area, to act as a control of the bending strength of unmodified bifurcations.

In December 2011, the replicate number and scope of this experiment was expanded. A total of 50 further hazel bifurcations were artificially altered; 25 bifurcations had a $3 \mathrm{~mm}$ diameter steel rod, fixed by bolts and washers, fitted through the center of both branches approximately $70 \mathrm{~mm}$ above the bifurcation to conjoin these branches (Figure 2A); a further 25 bifurcations were carefully split by hand so that a crack (approximately half the length of the branch bark ridge) was induced at the bifurcation apex by bending the two branches above the bifurcation away from each other (Figure 2C). The braced bifurcations were typically of a larger size (as measured by the parent stem diameter) than the mean of all the bifurcations at the start of the experiment, because of the need for the two branches of the bifurcation to be thick enough to accept the bracing rod and remain intact.

It was also determined at this time to add a further 70 normally formed bifurcations to the original 50 normally formed bifurcations, and also to identify in this shelterbelt 70 bark-included bifurcations for rupture testing. All additions were also marked with colorcoded fluorescent forest marking paint to aid their re-identification upon harvesting.

It was considered that a greater number of normally formed bifurcations were required, as some would be subsequently drilled immediately prior to mechanical testing to compare with those drilled bifurcations that were left in situ to grow and had remodeled around their drill hole due to subsequent secondary growth.

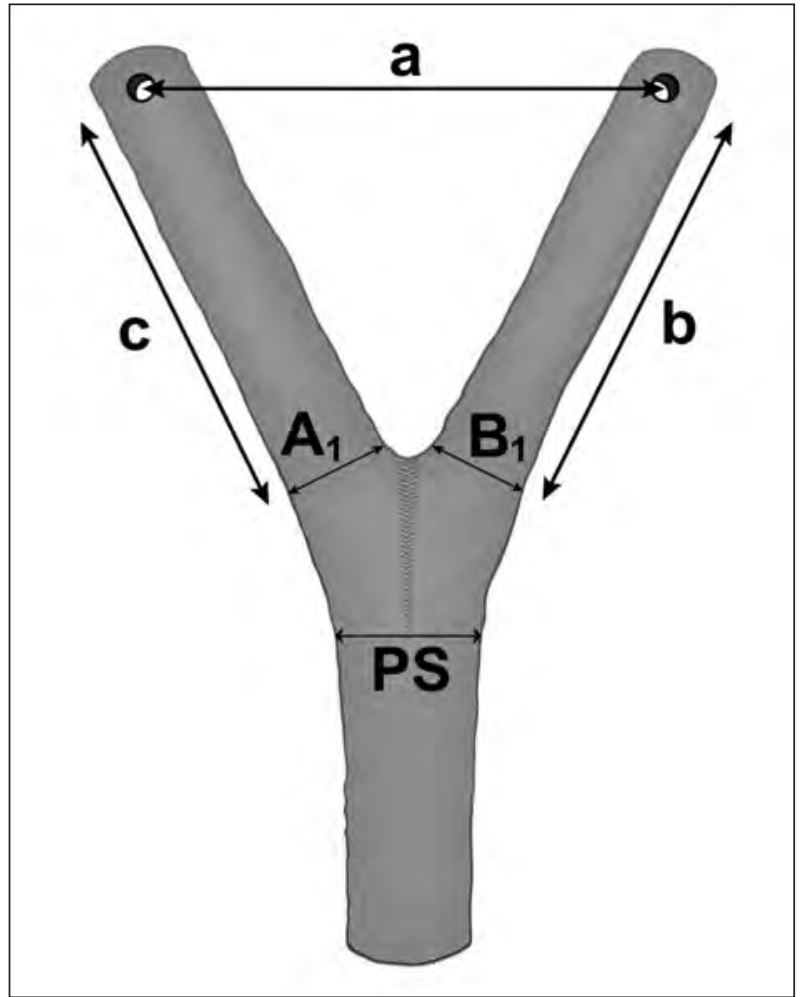

Figure 3. Measurements taken on each bifurcation in order to calculate its breaking stress: Distances between the two drill holes and between each drill hole and the apex of the bifurcation $(a, b$, and $c$ ) measured using a metal rule, diameters of the two branches just above the bifurcation apex, both in-line with the plane of the bifurcation $\left(A_{1}\right.$ and $\left.B_{1}\right)$ and perpendicular to the plane of the bifurcation $\left(A_{2}\right.$ and $B_{2}$ (not shown), and the diameter of the parent stem (PS) just below the branch bark ridge, both in the plane and perpendicular to the plane of the bifurcation measured using digital calipers.

Table 1. Determination of drill size for hazel bifurcations modified by drilling, based on the diameter of the parent stem, measured just below the termination of the branch bark ridge and perpendicular to the bifurcation.

\begin{tabular}{ll}
\hline $\begin{array}{l}\text { Diameter of parent stem }(\mathrm{mm}) \\
\text { perpendicular to bifurcation }\end{array}$ & $\begin{array}{l}\text { Drill size used } \\
\text { upon bifurcation }\end{array}$ \\
\hline Up to 22.5 & $4 \mathrm{~mm}$ \\
$22.5-27.49$ & $5 \mathrm{~mm}$ \\
$27.5-32.49$ & $6 \mathrm{~mm}$ \\
$32.5-37.49$ & $7 \mathrm{~mm}$ \\
$37.5-42.49$ & $8 \mathrm{~mm}$ \\
$42.5-47.49$ & $9 \mathrm{~mm}$ \\
$47.5+$ & $10 \mathrm{~mm}$ \\
\hline
\end{tabular}

By increasing the replicates within the normally formed group, researchers also hoped to reduce the variability in the mean breaking stress in that group, providing a better comparison between treatment types. The barkincluded bifurcations were added as a group 
type to compare with the extent of any strength loss in the artificially modified bifurcations and thus give additional context to the results.

A summary of the different types of bifurcation investigated is provided in Table 2 .

\section{Observations}

Prior to harvesting of the bifurcations in 2013 and 2015, basic observations were recorded of the condition and morphology of the selected bifurcations, including any swellings associated with the artificially-modified bifurcations, and also whether bifurcations had failed in situ, prior to harvesting, within the shelterbelt.

\section{Mechanical Testing}

In January 2013, after two growing seasons, 21 of the bifurcations that were drilled in December 2010, and 50 of the normally formed bifurcations, were cut from the trees in order to carry out mechanical testing. The bifurcations were cut so that there was a minimum length of $220 \mathrm{~mm}$ of both branches and at least twice the length of the branch bark ridge of the parent stem on each bifurcation. The bifurcations were wrapped in individual plastic bags immediately after cutting to minimize sap loss, and were stored in a cold store kept at $2^{\circ} \mathrm{C}$ prior to rupture testing.

Twenty-five of the normally formed bifurcations had the center of their apex drilled immediately prior to rupture testing, using the drill sizes as defined in Table 1.

A six-millimeter hole was drilled perpendicular to the plane of the bifurcation in the middle of both branches of each bifurcation, approximately $200 \mathrm{~mm}$ from the bifurcation apex, and then it was bolted to the crosshead and base of a universal testing machine (UTM) (Model 4301, Instron ${ }^{\oplus}$, Norwood, Massachusetts, U.S.), fitted with a $1 \mathrm{kN}$ load cell (Figure 4). The cross-

Table 2. Bifurcation types tested, research related to each type, numbers of replicates for each type, year of modification, and associated growing seasons prior to mechanical testing.

\begin{tabular}{|c|c|c|c|c|c|}
\hline $\begin{array}{l}\text { Name of } \\
\text { bifurcation type }\end{array}$ & Description & Factor assessed & $\begin{array}{l}\text { No. of } \\
\text { replicates }\end{array}$ & $\begin{array}{l}\text { Year of artificial } \\
\text { modification }\end{array}$ & $\begin{array}{l}\text { Growing seasons } \\
\text { between modification } \\
\text { and testing }\end{array}$ \\
\hline Bark-included & $\begin{array}{l}\text { Naturally-occurring bifurcations with } \\
\text { bark found to be incorporated within the } \\
\text { apex of the bifurcation (Figure 6). }\end{array}$ & $\begin{array}{l}\text { Effect of bark obstructing the } \\
\text { normal anatomical connection at } \\
\text { a bifurcation. }\end{array}$ & 70 & Not modified & N/A \\
\hline Braced & $\begin{array}{l}\text { Normally-formed bifurcations modified } \\
\text { by the conjoining of the two branches } \\
\text { above the bifurcation with a } 3 \mathrm{~mm} \text { steel } \\
\text { rod fitted through both branches, with a } \\
7 \mathrm{~mm} \text { washer and nut fitted at each end } \\
\text { of the rod. These were left to grow within } \\
\text { the tree's crown for three years prior to } \\
\text { testing (Figure 1A). }\end{array}$ & $\begin{array}{l}\text { Effect upon remodeling by } \\
\text { completely preventing mechanical } \\
\text { perturbation at the apex } \\
\text { of the bifurcation. }\end{array}$ & 25 & 2011 & 3 \\
\hline Newly drilled & $\begin{array}{l}\text { Normally-formed bifurcations drilled at } \\
\text { their apices using a drill-size as defined } \\
\text { in Table } 1 \text {, immediately prior to } \\
\text { mechanical testing (Figure 1B). }\end{array}$ & $\begin{array}{l}\text { Effect of removing centrally } \\
\text { placed interlocking xylem at } \\
\text { the apex of the bifurcation. }\end{array}$ & 60 & 2015 & 0 \\
\hline Normally formed & $\begin{array}{l}\text { Naturally occurring bifurcations with } \\
\text { no flaws observed in morphology. }\end{array}$ & $\begin{array}{l}\text { To act as a benchmark for all } \\
\text { other modifications. }\end{array}$ & 60 & Not modified & N/A \\
\hline Pre-drilled & $\begin{array}{l}\text { Normally-formed bifurcations modified } \\
\text { by drilling at their apices using a drill-size } \\
\text { as defined in Table } 1 \text {, and left to grow } \\
\text { within the tree's crown for two or four } \\
\text { years prior to testing (Figure 1B). }\end{array}$ & $\begin{array}{l}\text { Effect of remodeling after the } \\
\text { removal of the centrally placed } \\
\text { interlocking xylem at the apex } \\
\text { of the bifurcation. }\end{array}$ & 50 & 2010 & 2 and 4 \\
\hline Pre-split & $\begin{array}{l}\text { Normally-formed bifurcations modified } \\
\text { by carefully splitting the apex by hand, } \\
\text { by bending away from each other the two } \\
\text { arising branches. These were left to grow } \\
\text { within the tree's crown for three years } \\
\text { prior to testing (Figure } 1 \mathrm{C} \text { ). }\end{array}$ & $\begin{array}{l}\text { Effect of remodeling after the } \\
\text { cracking of the top part } \\
\text { of the bifurcation. }\end{array}$ & 25 & 2011 & 3 \\
\hline
\end{tabular}


head of the testing machine was then made to rise at a rate of $35 \mathrm{~mm} \mathrm{~min}^{-1}$ until each bifurcation was broken, while an interfacing computer recorded the displacement $(\mathrm{mm})$ and force applied $(\mathrm{N})$ at a rate of 10 measurements per second.

After this testing, careful observation was made, by eye, of the fracture surfaces of all bifurcations, in relation to their morphology and appearance.

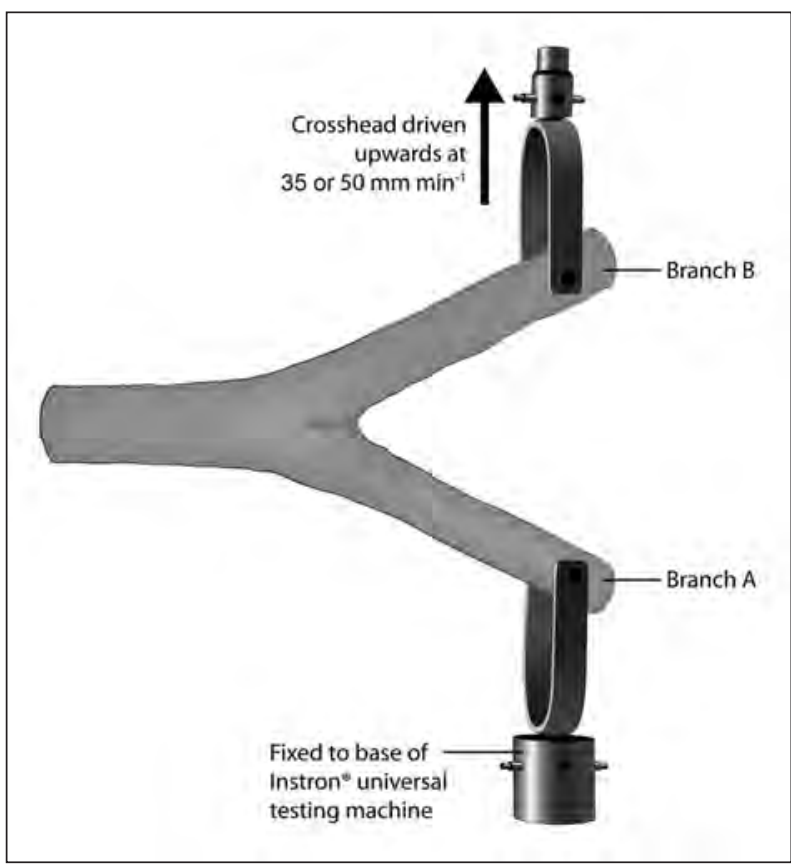

Figure 4. Diagram of the means of attachment of the bifurcations to the universal testing machine during the rupture tests.

In order to estimate their breaking stress, the following measurements were taken for each bifurcation: the diameter of both branches adjacent to the apex of the bifurcation perpendicular and in-line with the plane of the bifurcation $\left(A_{1}, A_{2}, B_{1}\right.$, and $B_{2}$ ); the diameter of the parent stem just below the branch bark ridge, perpendicular and in-line with the plane of the bifurcation ( $P S_{1}$ and $\left.P S_{2}\right)$; and the distances between the two drill holes in the two branches and between both drill holes and the apex of the bifurcation ( $a, b$, and $c$ ) (Figure 3).

This method of rupture testing of hazel bifurcations was used by Slater and Ennos (2015), when they assessed the strength of hazel bifurcations containing bark-inclusions, and the same equations were used to estimate the breaking stress of the bifurcations as are reported in this previous paper.
To assist with comparing the relative strength of the bifurcations, three-point bending tests of the smaller diameter branch of the bifurcation were carried out, testing the yield strength of the middle of each branch whose structure had not been compromised by the rupture testing. The span for these branches was set at $215 \mathrm{~mm}$ for branches up to $20 \mathrm{~mm}$ in diameter and $275 \mathrm{~mm}$ for branches up to $23 \mathrm{~mm}$ in diameter, and the crosshead of the UTM, fitted with a semicircular plastic probe, pressed down on the branch at a rate of $30 \mathrm{~mm} \mathrm{~min}^{-1}$ until the branch yielded substantially, with the interfacing computer recording force, displacement, and calculating the yield strength of each branch tested. This procedure was used successfully in previous testing (Slater and Ennos 2013; Slater and Ennos 2015). Due to limitations of the testing machine in terms of the span length that could be used and the maximum load $(900 \mathrm{kN})$ that could be applied, branches with a mid-diameter of over $23 \mathrm{~mm}$ could not be tested to their yield point. Careful observations of the yielding of each branch was undertaken, as these shorter spans could have resulted in shear failures (Vincent 2012) that could have invalidated some of the test specimens; however, no shear failures were observed to occur in these test specimens.

In February 2015, after four growing seasons for the original set of drilled bifurcations and three growing seasons for the braced and split bifurcations, all the remaining bifurcations were cut from the hazel trees and subjected to the same method of bagging, storage, and rupture testing. A different testing machine (Model 3344, Instron, Norwood, Massachusetts, U.S.) had to be used for this second set of mechanical tests, as the original UTM suffered a breakdown in the two-year period between these two tests. The parameters of the rupture tests were the same in nearly all respects; however, the rate of displacement was increased to $50 \mathrm{~mm} \mathrm{~min}^{-1}$, due to the large number of bifurcations that had to be processed. This higher rate of displacement for this second set of tests did not make any discernible difference to the kinematics of failure.

The bifurcations with bark included within them were classified after testing in terms of the relative occlusion of the bark into the bifurcation, giving rise to three types of bark inclusion: embedded, 
cup-shaped, and wide-mouthed (Figure 5). This classification of bark inclusions was used by Slater and Ennos (2015), who identified significant differences in breaking stress between these three morphological types of bark-included bifurcation in hazel. For each braced bifurcation tested, bolt cutters were used to cut the steel rod that conjoined their two branches in two places prior to testing.

\section{Wood Density Testing}

Wood density tests were carried out on small samples of the xylem excised from the apices, from the side of the bifurcations adjacent to their apices, and from the parent stems of all the bifurcations tested in 2015. The purpose of this testing was to ascertain if the remodeling around the induced defects also affected the mechanical qualities of the new wood being laid around these defects. Both braced and normally formed bifurcations could provide xylem from all three locations, whereas the drilled or split bifurcations and those with included bark could only supply xylem samples from the side of the bifurcation apex and the stem (Figure 2B; Fig- ure 2C; Figure 6). Samples were cut using a pull saw and billhook blade, their fresh weight taken, and their volume calculated by measuring the displacement weight when each sample was immersed in distilled water on a weighing scale. The mean volume of these samples, for this wood density test, was $444.4 \mathrm{~mm}^{3} \pm 8.4 \mathrm{SE}$ (standard error).

The samples were then oven-dried for 96 hours at $60^{\circ} \mathrm{C}$ and their dry weight recorded. Given the small size of the samples, this length of drying time was considered sufficient. Wood density was calculated by dividing the dry weight of each sample by the volume of the sample (Hughes 2005).

\section{Statistical Analysis}

All statistical tests were carried out using Minit$\mathrm{ab}^{\circledast}$ statistical software (version 17, Minitab Inc., State College, Pennsylvania, U.S.). $\mathrm{A} \chi^{2}$ test was used to assess whether there were differences in modes of failure for the bifurcation types.

For comparisons between bifurcation types, and for sub sets within each bifurcation type, General Linear Model (GLM) ANOVAs were used to find

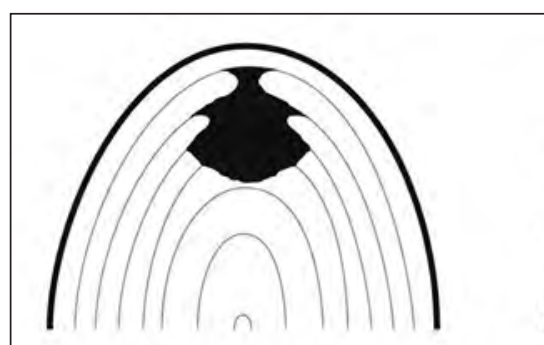

EMBEDDED

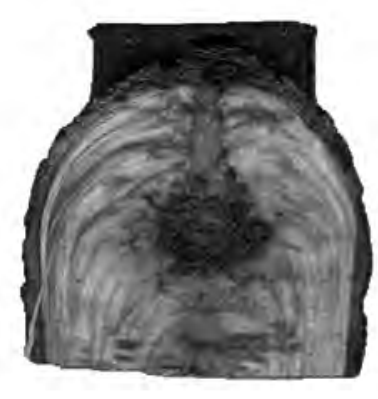

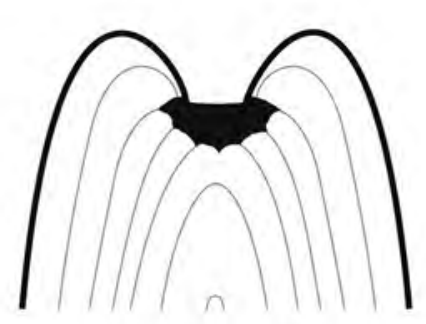

CUP-SHAPED

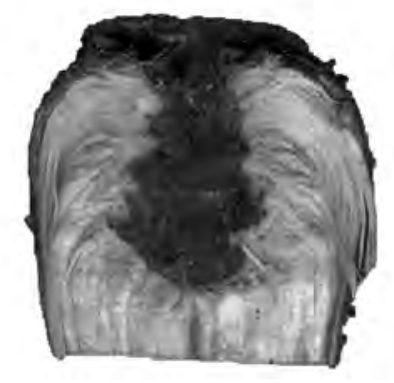

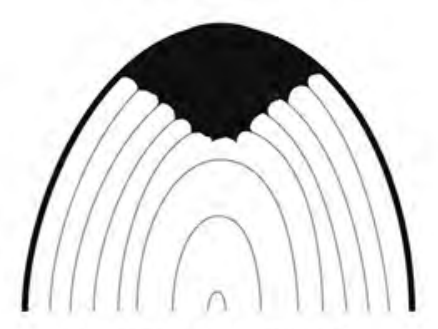

WIDE-MOUTHED BARK INCLUSION

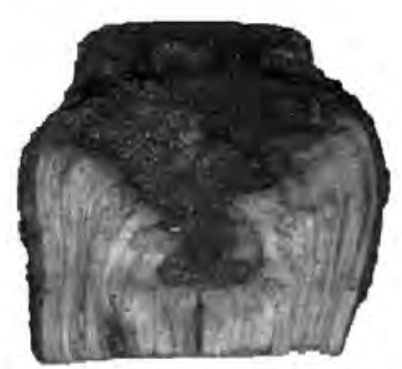

Figure 5. Diagrams and images defining three morphological types of bark-included junctions in hazel, based on observations of the fracture surfaces of bifurcations. Embedded bark is surrounded entirely by xylem, the bark having been occluded into the junction. A cup-shaped bark inclusion has sapwood formed around included bark that lies at the center of the join; there is sapwood at the apex of the bifurcation rather than bark. A widemouthed bark inclusion has a substantial width of included bark at the apex of the bifurcation, situated above any connecting sapwood. 


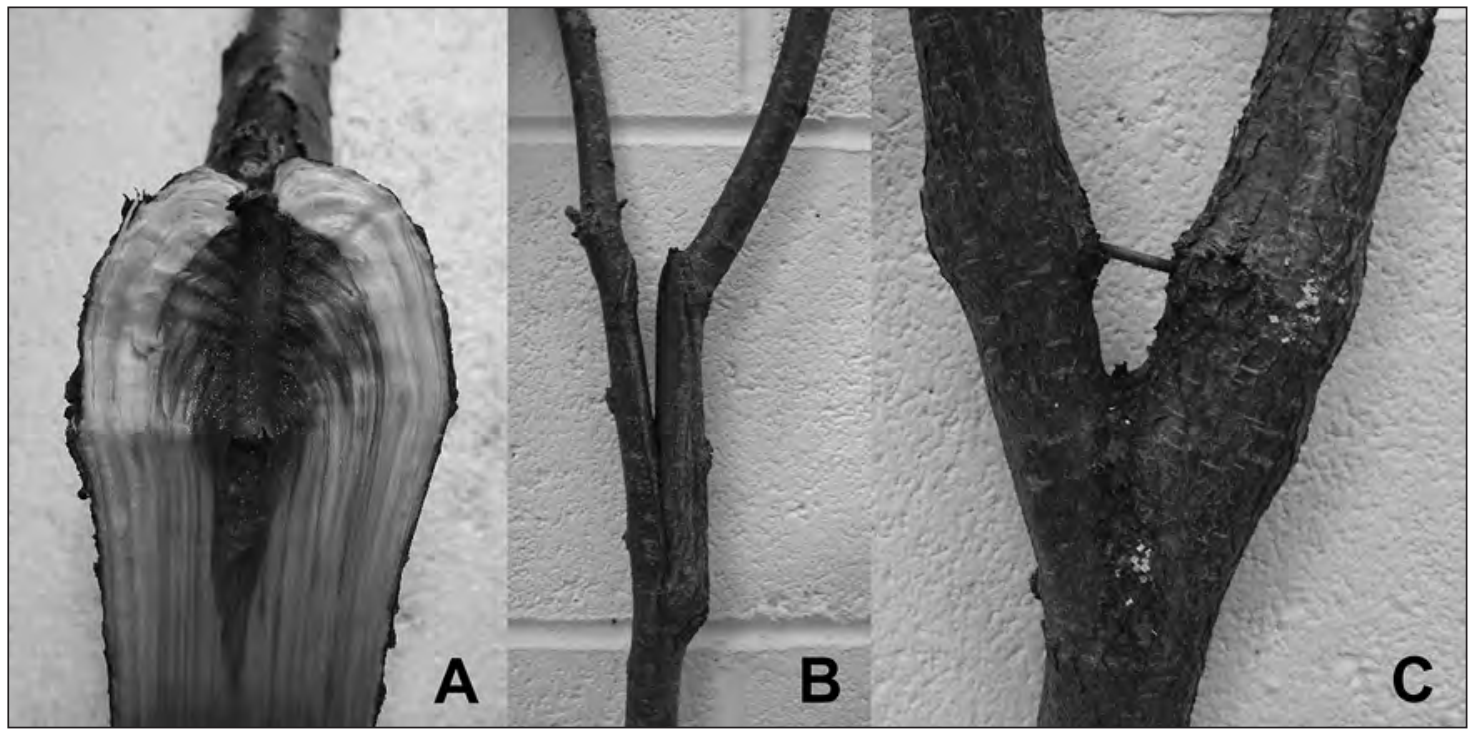

Figure 6. A) Fracture surface of a pre-drilled bifurcation after two growing seasons, showing the silicon inserted into the initial drill hole, dysfunction induced in the sapwood around the drill hole (discolored area) and the remodeling of the sapwood to form a cup-shaped union. B) Typical deformation of a pre-split bifurcation, where the crack had subsequently propagated to a knot in the parent stem and then been arrested. C) Typical deformation of the branches of a braced bifurcation around the implanted steel rod, after three years of growth, showing adverse taper in the smaller branch.

differences in mean breaking stress, with the parent stem diameter $\left(P S_{1}\right)$ and the diameter ratio of the bifurcations as covariates where appropriate, in combination with a post hoc Tukey test at a 5\% confidence level. Residuals were assessed for the normality of their distribution using the Anderson-Darling test. For the ANOVA assessing the bending strength of all types of bifurcations (Figure 7), residuals of the transformed data satisfied the Anderson-Darling test for normality $\left(A D_{299}=0.695 ; P=0.07\right)$. Likewise, for the ANOVA assessing the bending strength of different types of bark-included bifurcations, residuals satisfied the Anderson-Darling test for normality $\left(A D_{66}=0.359 ; P=0.441\right)$. For the ANOVA assessing the pre-drilled bifurcations (Figure $8)$, the residuals satisfied the Anderson-Darling test for normality $\left(A D_{94}=0.698 ; P=0.066\right)$.

To determine if the branches of the braced bifurcations exhibited adverse taper, a paired t-test comparing the diameter of the branches above the fitted steel brace and at the apex of the bifurcation was carried out.

To determine differences between the wood density of samples extracted from the apices and sides of bifurcations and the adjacent stem wood, a GLM ANOVA with sample volume as a covariate was used, in combination with a post hoc Tukey test at a 5\% confidence level. Residuals were assessed for the normality of their distribution using a Kolmogorov-Smirnov test, as the Anderson-Darling test gave a marginal result. Residuals from the ANOVA assessing differences in wood density satisfied the Kolmogorov-Smirnov test for normality $\left(K S_{372}=0.046 ; P=0.059\right)$. For

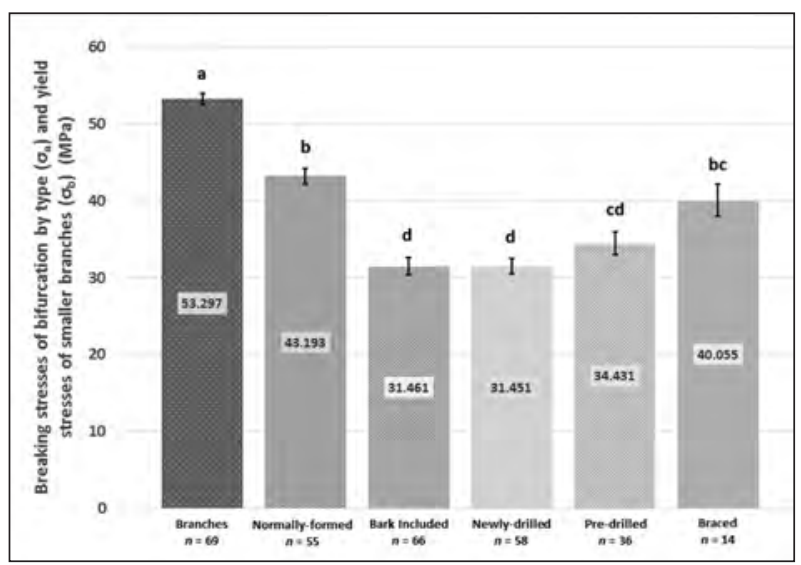

Figure 7. Mean breaking stresses for the main bifurcation types tested (excluding branch failures) and the mean yield stress of the smaller branches as found by three-point bending. The pre-split type is not included as its replicate number was too small to be statistically analyzed $(n=2)$. Error bars represent standard error. Letters above bars identify significant differences between groups by using a GLM ANOVA and post hoc Tukey test at a $5 \%$ confidence limit. 
assessing the difference between wood density in normally formed and braced bifurcations, residuals from this ANOVA satisfied the Anderson-Darling test for normality $\left(A D_{100}=0.512 ; P=0.191\right)$.

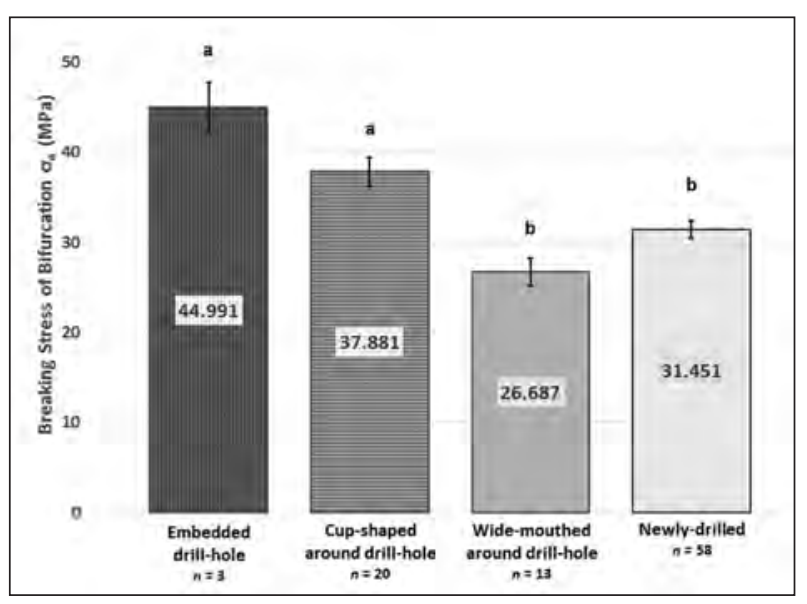

Figure 8. Mean breaking stresses of the three types of predrilled bifurcation tested. Error bars represent standard error. Letters above bars identify significant differences between groups through using a GLM ANOVA and post hoc Tukey test at a $5 \%$ confidence limit $\left(F_{3,88}=5.70 ; R^{2}=42.34 \%\right.$; $P=0.001)$. The diameter ratio was a significant covariate $(P<0.001)$, and the parent stem diameter was not significant $(P=0.909)$

\section{RESULTS}

\section{Specimen Losses and Mean Specimen Dimensions}

Over the four years of this experiment, a number of the selected bifurcations (20 out of the total 290 bifurcations) were lost prior to the mechanical testing. Fourteen of the bifurcations were removed from this study in 2012, as a length of the shelterbelt's edge was accidentally flailed when a neighboring hedgerow was pruned; the remaining six bifurcations that were lost could not be found in 2015 due to the biodegradability of the forestry marker paint used, as it was concluded that the paint had weathered away.

In addition, two types of the modified bifurcations suffered replicate losses for other reasons. Seven of the braced bifurcations grew, over the three years, to a size that was too large for the testing machine to break them (having started at the upper end of the parent stem diameter sizes chosen), which reduced this group's size to 14 testable replicates. Twenty of the twenty-five split bifurcations suffered windinduced mechanical failure over the three years they were in situ. For this latter group, observations were subsequently made of these failures and of the morphology of the five bifurcations that remained.

The mean parent stem diameter $\left(P S_{1}\right)$ for the remaining 243 bifurcations was $30.35 \mathrm{~mm} \pm 0.37$ $\mathrm{SE}$, the mean diameter of the smaller branch of the bifurcation just above its point of attachment $\left(b_{1}\right)$ was $21.23 \mathrm{~mm} \pm 0.26 \mathrm{SE}$, and the mean diameter ratio for these bifurcations was $80.98 \pm 0.75 \%$ SE.

\section{Observations of Bifurcations Prior to Testing}

\section{Bark-included bifurcations}

Ten of the normally formed bifurcations were found to contain embedded bark, so the data generated from these 10 bifurcations was moved to the bark-included group for analysis. To compensate for the reduction in the group size of the normally formed bifurcations, the number of replicates allotted to the newly drilled group was reduced to obtain a roughly equal number of replicates within these two groups. The categorization of the remaining 58 bark-included bifurcations resulted in 36 being identified as wide-mouthed bark inclusions and 22 identified as cup-shaped bark inclusions (Figure 5).

\section{Drilled bifurcations}

Observations of the pre-drilled bifurcations showed a range of remodeling responses to the initial drilling of the hole at their apices. In general, despite some initial dysfunction caused to adjacent tissues after drilling, additional sapwood had grown around the induced defect (Figure 6A). Three of these bifurcations had fully embedded the silicon, surrounding it with new sapwood after four years of growth, and many more had started to cover over the top of the drill hole. In the majority of these bifurcations a general swelling in the location of the branch bark ridge was evident. For 13 of these bifurcations, however, the drill hole had initiated the development of included bark at the apex or a larger extent of associated dysfunction around the original drill hole had resulted in a failure to occlude the drill hole. No significant volume of decayed xylem was found in any of these bifurcations. This difference in development allowed the pre-drilled bifurcations to be classified into three sub-categories to match the bark-included ones: i) 
that the silicon in the drill hole had become embedded; ii) that the bifurcation was forming a cup shape around the drill hole; or iii) that the drillhole was still wide open at the bifurcation's apex.

\section{Split bifurcations}

For the pre-split bifurcations, the high number of replicate losses through wind-induced failure was investigated. It was observed that for the five split bifurcations that had persisted for three years and been subjected to rupture testing, all had split further down the stem since the initial splitting was carried out in 2013, and the split had been halted either by encountering a substantial knot in the parent stem (for four of them) or a substantial bend in the parent stem (in one case only). The 20 bifurcations that had mechanically failed had done so due to natural wind-induced movement and subsequent propagation of the original split down the parent stem, with the split at some point deviating to the edge of the stem, causing one branch to fall away from the tree.

The propagation of these splits and the failure of so many of this type of bifurcation meant that this group had to be excluded from any statistical analysis relating to the breaking stresses of the bifurcations. An image of the typical surviving pre-split bifurcation is provided in Figure 7.

\section{Braced bifurcations}

It was evident that the installation of the steel rod in 2011 had resulted in abnormal swelling of the branches at the point of drilling the $3 \mathrm{~mm}$ hole needed to fit the brace (Figure 6C). All braced bifurcations exhibited some level of occlusion of the rod, nuts, and washers, and some had wholly occluded the nuts and washers. Measurements were taken of the diameter of the branches just above each braced bifurcation's apex, as with all other bifurcations, but also the branch diameters were measured at the point above the bracing rod and its associated swelling, to determine if the bracing had resulted in the branches developing adverse taper.

\section{Mechanical Testing}

\section{All bifurcation types}

Twelve of the tested bifurcations suffered branch failure, rather than failing at the bifurcation itself. To assess bifurcation strength, all those bifurcations that suffered branch failure were excluded from this part of the data analysis.

A statistical comparison was made of the mean breaking stresses of the main five bifurcation types and the yield stress of the smaller branches, using a GLM ANOVA and post hoc Tukey test after a natural log transformation of the data. It was found that there were significant differences between groups $\left(F_{5,293}=61.54 ; R^{2}=51.23 \% ; P<0.001\right)$; pairwise comparisons identified that the branches yielded at the highest mean stress, and the bark-included and newly drilled bifurcations broke at the lowest mean stress (Figure 7).

\section{Bark-included bifurcations}

A comparison between the three sub-types of the bark-included bifurcations in relation to their mean breaking stress is provided in Figure 9. A GLM ANOVA $\left(F_{2,61}=10.44 ; R^{2}=38.93 \%\right.$; $P<0.001)$ with diameter ratio and the diameter of the parent stem as covariates found that there were significant differences between these groups and a post hoc Tukey test identified that the wide-mouthed bark inclusions broke apart at a lower stress than the other two types. The diameter ratio was a significant covariate $(P<$ $0.001)$ in that a higher diameter ratio resulted in a lower breaking stress, but the parent stem diameter was not a significant covariate $(P=0.381)$.

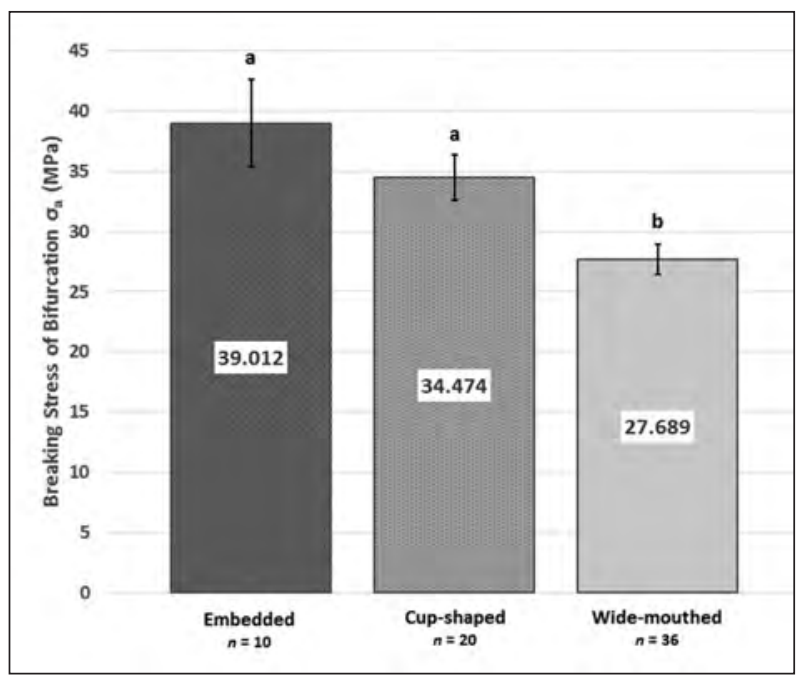

Figure 9. Mean breaking stresses of the three types of barkincluded bifurcation tested. Error bars represent standard error. Letters above bars identify significant differences between groups by using a GLM ANOVA and post hoc Tukey test at a $5 \%$ confidence limit. 
The difference in bending strength between these three types of bark-included bifurcations and the normally formed bifurcations was a reduction of $9.7 \%$ in bending strength for those with embedded bark, a reduction of $20.2 \%$ for cupshaped bifurcations, and a reduction of $35.9 \%$ for wide-mouthed bark-included bifurcations.

\section{Drilled and pre-drilled bifurcations}

The mean breaking stress of the newly drilled bifurcations was $31.45 \mathrm{MPa} \pm 1.01 \mathrm{SE}$, whereas for the pre-drilled bifurcations that were allowed to grow for two growing seasons it was 32.85 $\mathrm{MPa} \pm 1.85 \mathrm{SE}$, and for the pre-drilled bifurcations that remodeled around the drill holes for four growing seasons it was $36.64 \mathrm{MPa} \pm 2.35 \mathrm{SE}$.

It was observed that growth responses in the pre-drilled bifurcations were mixed, with some bifurcations suffering more xylem and cambial dysfunction than others, and some growing rapidly around the drill hole with little to no dysfunction evident. As a consequence, the pre-drilled bifurcations were placed into three groups corresponding to the classification of the bark-included group in this study: three of the pre-drilled bifurcations had occluded the drill hole and were categorized as embedded, 20 more bifurcations had partly occluded the drill hole and were categorized as cup-shaped, and the remaining 13 bifurcations in the pre-drilled group exhibited no evidence of occlusion and had suffered dieback related to the drill hole; these were categorized as wide-mouthed. A statistical comparison between these groups and the newly drilled bifurcations is provided in Figure 8.

Bifurcations in the pre-drilled group that showed the most regrowth around the drill hole (embedded or cup-shaped) had a higher strength than those where regrowth had not occurred (wide-mouthed), which had similar strength to the newly drilled bifurcations (Figure 8).

\section{Braced bifurcations}

For the braced bifurcations, the mean diameter of the branches arising from the bifurcations was $24.59 \mathrm{~mm} \pm 1.01 \mathrm{SE}$, but the mean diameter of the branches just above the bracing rod was $28.40 \mathrm{~mm} \pm 1.01 \mathrm{SE}$. A paired t-test identified that a significant adverse taper had devel- oped in the branches $\left(T_{1,13}=4.75 ; P<0.001\right)$. Data were normally distributed $\left(A D_{28}=0.643\right.$; $P=0.084)$. This adverse branch taper was not exhibited by any other bifurcation type.

Further to this observation, the breaking stress of these braced bifurcations was additionally calculated based on the section modulus of the smaller branch just above the steel rod brace and its associated swelling. This further assessment takes into account the larger branch that would actually have to be borne by the bifurcation if the brace was not in place. The mean breaking stress of the braced bifurcations using the section modulus of the smaller branch at the bifurcation apex was $40.06 \mathrm{MPa}$ \pm 2.08 SE (Figure 7), but when taking into account the section modulus of that same branch above the brace, the equivalent breaking stress reduced to only $30.47 \mathrm{MPa} \pm 1.44$ SE. These two mean breaking stresses were compared with the mean breaking stresses of the normally formed bifurcations (Figure 10).

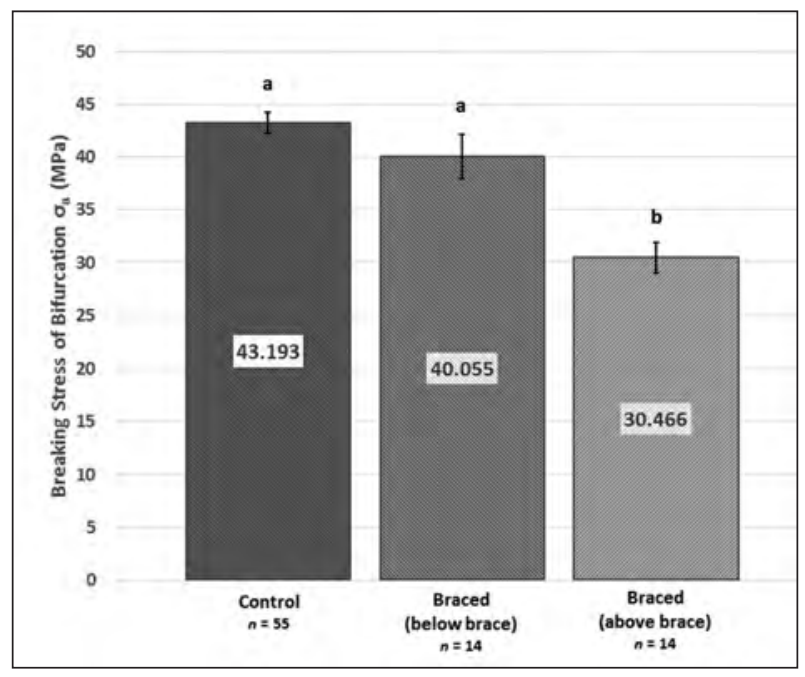

Figure 10. Mean breaking stresses of the normally formed bifurcations and the two estimates of the breaking stresses of the braced bifurcations, taking into account the section modulus of the smaller branch either below or above the brace rod. Error bars represent standard error. Letters above bars identify significant differences between groups by using a GLM ANOVA and post hoc Dunnett test at a $5 \%$ confidence limit $\left(F_{3,77}=19.32 ; R^{2}=35.59 \% ; P<0.001\right)$. The diameter ratio was a significant covariate $(P=0.017)$, with an increasing diameter ratio resulting in a lowering of breaking stress; the parent stem diameter was not found to be a significant factor $(P=0.631)$. 


\section{Wood density at hazel bifurcations}

The results of the wood density testing are provided in Table 3. Statistical analysis of the data found that all the samples excised from under the branch bark ridge were significantly denser than those excised from the adjacent stem. Overall, samples from the side of the bifurcation apex $(n$

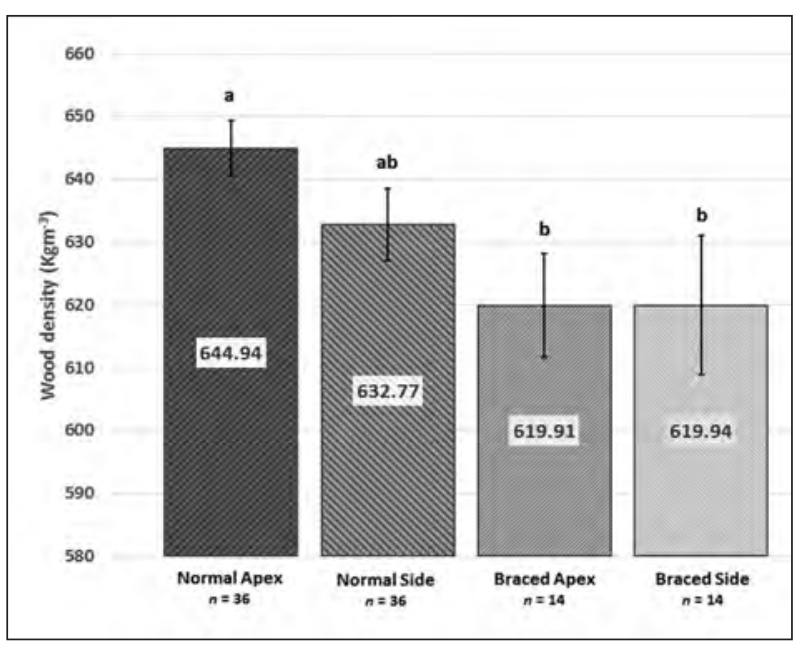

Figure 11. Mean wood density of samples excised from the apices and sides of normally formed and braced bifurcations. Letters above bars identify differences between groups by using a GLM ANOVA and post hoc Tukey test at a $5 \%$ confidence limit.
$=161$ ) were $27.1 \%$ denser than the samples from the stem, and the highest mean density was found at the apex of the normally formed bifurcations.

A significant difference in the wood density of normally formed and braced bifurcations was also identified using a GLM ANOVA $\left(F_{3,96}=3.16\right.$; $\left.R^{2}=8.99 \% ; P=0.028\right)$ and post hoc Tukey test (Figure 11). The samples from the apices of the normally formed bifurcations were $4 \%$ denser than the samples from the braced bifurcations.

\section{DISCUSSION}

This study has successfully identified the extent by which both the natural and experimentally induced defects weakened these hazel bifurcations, and that remodeling can potentially overcome these defects due to changes in growth probably caused by mechanical strain.

\section{Bark-Included Bifurcations}

The findings from this assessment of barkincluded bifurcations support those of Slater and Ennos (2015) in that bifurcations with widemouthed bark inclusions were significantly weaker than those with a cup-shaped morphology, and

Table 3. Wood density of samples taken from different bifurcation types tested, by location. Letters (A, AB, B, and C) below the mean in each entry identify differences between these means across bifurcation type and location of xylem extraction, as identified by a GLM ANOVA with the sample volume as a covariate and post hoc Tukey test at a $5 \%$ confidence limit $\left(F_{13.357}=93.94 ; R^{2}=78.09 \% ; P<0.001\right)$. Sample volume was not a significant factor in the differences found in wood density between groups $(P=0.509)$.

\begin{tabular}{|c|c|c|c|}
\hline \multirow[t]{2}{*}{ Bifurcation type } & \multicolumn{3}{|c|}{ Wood density of extracted sample $\left(\mathrm{Kg} \mathrm{m}^{-3}\right)$, by location } \\
\hline & Apex & Side & Stem \\
\hline Normally formed & $\begin{array}{l}644.9 \pm 4.3 \mathrm{SE} \\
\mathrm{A} \\
\mathrm{n}=36\end{array}$ & $\begin{array}{l}632.8 \pm 5.8 \mathrm{SE} \\
\mathrm{A} \\
\mathrm{n}=36\end{array}$ & $\begin{array}{l}493.0 \pm 6.9 \mathrm{SE} \\
\mathrm{C} \\
\mathrm{n}=36\end{array}$ \\
\hline Bark-included & $\mathrm{N} / \mathrm{A}$ & $\begin{array}{l}628.6 \pm 5.3 \mathrm{SE} \\
\mathrm{AB} \\
\mathrm{n}=57\end{array}$ & $\begin{array}{l}490.9 \pm 5.2 \mathrm{SE} \\
\mathrm{C} \\
\mathrm{n}=57\end{array}$ \\
\hline Newly drilled & $\mathrm{N} / \mathrm{A}$ & $\begin{array}{l}628.9 \pm 5.8 \mathrm{SE} \\
\mathrm{AB} \\
\mathrm{n}=30\end{array}$ & $\begin{array}{l}488.7 \pm 7.6 \mathrm{SE} \\
\mathrm{C} \\
\mathrm{n}=30\end{array}$ \\
\hline Pre-drilled & $\mathrm{N} / \mathrm{A}$ & $\begin{array}{l}595.0 \pm 4.7 \mathrm{SE} \\
\mathrm{B} \\
\mathrm{n}=19\end{array}$ & $\begin{array}{l}494.8 \pm 12.2 \mathrm{SE} \\
\mathrm{C} \\
\mathrm{n}=19\end{array}$ \\
\hline Pre-split & $\mathrm{N} / \mathrm{A}$ & $\begin{array}{l}614.6 \pm 5.7 \mathrm{SE} \\
\mathrm{AB} \\
\mathrm{n}=5\end{array}$ & $\begin{array}{l}503.2 \pm 22.5 \mathrm{SE} \\
\mathrm{C} \\
\mathrm{n}=5\end{array}$ \\
\hline Braced & $\begin{array}{l}619.9 \pm 8.3 \mathrm{SE} \\
\mathrm{AB} \\
\mathrm{n}=14\end{array}$ & $\begin{array}{l}619.9 \pm 11.0 \mathrm{SE} \\
\mathrm{AB} \\
\mathrm{n}=14\end{array}$ & $\begin{array}{l}480.0 \pm 6.7 \mathrm{SE} \\
\mathrm{C} \\
\mathrm{n}=14\end{array}$ \\
\hline
\end{tabular}


overall the bark-included bifurcations had only $72.8 \%$ of the strength of the normally formed bifurcations. Those bifurcations with embedded bark can be considered as ones that have remodeled successfully to occlude the bark that would otherwise have weakened them substantially.

\section{Drilled and Pre-Drilled Bifurcations}

Interestingly, the bifurcations that were drilled at the point of testing were found to have the same mean breaking stress as the bark-included bifurcations. Both of these bifurcation types lack the interlocking wood grain pattern at the apex of the bifurcation, as found using CT scanning by Slater et al. (2014), the former type by having it drilled out, the latter type by failing to develop it sufficiently.

The pre-drilled bifurcations showed progressive recovery of their bending strength by remodeling around the initial drill holes created and the dysfunction in adjacent tissues (Figure 6A; Figure 9). The level of recovery varied substantially: among other factors, this may have been due to the different positions that these bifurcations had within the crowns of the hazel trees. Given the widely accepted principle of thigmomorphogenesis in plants, and the evidence of atrophy in the braced bifurcations in this study, the bending moments experienced by these bifurcations when growing in situ are likely to be linked to the extent of their remodeling around these drill holes; however, to verify this, such bifurcations would need to be the subject of a more detailed analysis using tilt meters or accelerometers to assess them for differences in movement under dynamic wind loading. This remodeling will be related both to the initial wounding and the subsequent additional mechanical strain under dynamic loading (Steucek and Kellogg 1972).

\section{Split Bifurcations}

It is clear from the observations of wind-induced failure in $80 \%$ of these modified bifurcations that their factor of safety was compromised by initially inducing the splits in their apices. The five bifurcations that remained intact had remodeled lower down the parent stem, after the propagating crack had been arrested by a major change in woodgrain pattern and direction. This finding strongly suggests that the interlocking and denser wood at the apex of a hazel bifurcation is much-needed to prevent the initiation of cracks that would result in them splitting apart under the loading imposed by normal conditions. It should be noted that no other bifurcation type was observed to exhibit any wind-induced failures over the four-year period of this experiment. This implies that the bark-included and drilled bifurcations in this study had a factor of safety high enough that they could persist under the loading conditions that resulted in $80 \%$ of the split bifurcations failing over three growing seasons.

\section{Braced Bifurcations}

Despite the reduced number of replicates for this bifurcation type, the strength of the bifurcations and the wood density of the bifurcations' apices, when compared with normally formed bifurcations, strongly suggests that the effect of the rod-bracing was that these bifurcations atrophied in terms of their mechanical development. In contrast to the drilled bifurcations, the effect of putting in place a rigid brace will have prevented the braced bifurcations from experiencing mechanical strains at their apices.

The atrophying effect was significant but could be argued not to be very substantial if the diameter of the smaller branch at the bifurcation apex was used to assess the breaking stress. This result implies that mechanical loading is not the sole inducer of further sapwood developing in a given location: new layers of sapwood are needed for the provision of new tracheal elements through each component part of a tree's crown, even though some components may not experience substantial strains. However, for arborists considering installing a rod brace in a tree, they should take into account the subsequent development of branches with adverse taper, the associated decline in the strength of the braced bifurcation, and its increasing reliance upon the brace over time (Smiley et al. 2000). In this study, if the braced bifurcations were required to support the arising branches once the brace was removed, then these bifurcations had only $70.5 \%$ of the strength of the normally formed group, and their factor of safety would have been substantially eroded.

\section{Wood Density}

All the xylem formed under the branch bark ridge was substantially denser than that found in the adjacent parent stem, for all bifurcation types. A heightened wood density at the bifurcation is likely 
to result in a higher breaking stress for this component (Slater and Ennos 2013), although it is only one factor among many that will affect the breaking stress of any given bifurcation. The mean density of the wood formed at the apices of the braced bifurcations was $4 \%$ less dense than the wood at the apex of the normally formed bifurcations, suggesting that wood quality had atrophied in response to bracing.

\section{Limitations of the Study}

It is important to acknowledge that this study is based on data collected from semi-mature bifurcations in hazel trees, which gives rise to limitations in the scope of the subsequent findings. This study is part of a series that has examined bifurcations in this particular species to provide anatomical and mechanical models that could then be compared and contrasted to the bifurcations of other woody species by further study. The physiological pathways to this remodeling process were not examined as part of this study and could also be usefully examined in further research.

\section{CONCLUSIONS}

The denser xylem formed at the apex of bifurcations in hazel (and in other tree species) plays a key function in preventing failure at the junction (Slater and Ennos 2013). Although the role of this modified xylem is important in supplying a higher bending strength, its absence does not necessarily result in bifurcation failure: connections formed either side of the bifurcation apex can clearly be adequate to give four year's longevity or more to the juvenile bifurcations tested in these semi-mature hazel trees.

From the pre-drilled bifurcations in this study, it is clear that they can satisfactorily remodel around an induced injury or defect and recover their full bending strength over time. This complements the analysis of Slater and Ennos (2015) that indicates remodeling around included bark can also fully recover the strength of bifurcations in hazel. This process of repair was not uniform among the bifurcations in this study, and further research could seek to find key factors that relate to the rate of repair of such bifurcations. In contrast, if the hazel bifurcation is split at its apex, although it has the potential to remodel, it is much more likely that it will fail completely under further wind-loading due to the initial crack propagating further down the stem. If a rod brace is installed above a hazel bifurcation, then development of the bifurcation will atrophy, identifying that thigmomorphogenesis plays an important role in the mechanical development of bifurcations.

These findings help to measure the extent and degree of the remodeling of such bifurcations with different treatments, and could assist in determining a factor of safety for this component of a tree's crown. Further modeling needs to be extended beyond static rupture tests, to investigate the movement behavior of bifurcations under dynamic wind loading, which is considered to be a key factor in the impetus for bifurcations to remodel after injury or occlude a naturally occurring mechanical flaw, such as a bark inclusion.

Acknowledgments. We would like to thank the following contributors: Myerscough College, England, for sponsoring this research and for the supply of the hazel bifurcations for testing, and Austin Walmsley metal fabricators of Garstang, England, for the construction of the bespoken metal clamps that were used to attach the bifurcations to the Instron testing machines.

\section{LITERATURE CITED}

Badel, E., F.W. Ewers, H. Cochard, and F.W. Telewski. 2015. Acclimation of mechanical and hydraulic functions in trees: Impact of the thigmomorphogenetic process. Frontiers in Plant Science 6:266.

Biro, R.L., E.R. Hunt, Y. Erner, and M.J. Jaffe. 1980. Thigmomorphogenesis: Changes in cell division and elongation in the internodes of mechanically perturbed or ethrel-treated bean plants. Annals of Botany 45:655-664.

Braam, J., and R.W. Davis. 1990. Rain-, wind-, and touch-induced expression of calmodulin and calmodulin-related genes in Arabidopsis. Cell 60:357-364.

Coutand, C. 2010. Mechanosensing and thigmomorphogenesis, a physiological and biomechanical point of view. Plant Science 179:168-182.

Farnsworth, K.D., and K.J. Niklas. 1995. Theories of optimization, form and function in branching architecture in plants. Functional Ecology 9:355-363.

Gartner, B.L. 1995. Patterns of xylem variation within a tree and their hydraulic and mechanical consequences. In: G.L. Gartner (Ed.). Plant Stems: Physiological and Functional Morphology. Academic Press, New York, New York, U.S.

Gilman, E.F. 2003. Branch to stem diameter affects strength of attachment. Journal of Arboriculture 29:291-294.

Grace, J. 1977. Plant Responses to Wind. Academic Press, London, UK.

Hughes, S.W. 2005. Archimedes revisited: A faster, better, cheaper method of accurately measuring the volume of small objects. Physics Education 40(5):468-474.

Jaffe, M.J. 1973. Thigmomorphogenesis: The response of plant growth and development to mechanical stimulation. Planta 114:143-157. 
Jaffe, M.J., and S. Forbes. 1993. Thigmomorphogenesis: The effect of mechanical perturbation on plants. Plant Growth Regulation 12:313-324.

Jungnikl, K., J. Goebbels, I. Burgert, and P. Fratzl. 2009. The role of material properties for the mechanical adaptation at branch junctions. Trees: Structure and Function 23:605-610.

Kane, B., R. Farrell, S.M. Zedaker, J.R. Loferski, and D.W. Smith. 2008. Failure mode and prediction of the strength of branch attachments. Arboriculture \& Urban Forestry 34:308-316.

Lev-Yadun, S., and R. Aloni. 1990. Vascular differentiation in branch junctions of trees: Circular patterns and functional significance. Trees: Structure and Function 4:49-54.

Lonsdale, D. 1999. The Principles of Tree Hazard Assessment and Management. TSO, London, UK.

Mattheck, C., and W. Linnard. 1998. Design in Nature. Springer, Berlin, Germany.

Monshausen, G.B., and E.S. Haswell. 2013. A force of nature: Molecular mechanisms of mechanoperception in plants. Journal of Experimental Botany 64:4663-80.

Philipson, W., J.M. Ward, and B.G. Butterfield. 1971. The vascular cambium: Its development and activity. Chapman \& Hall Ltd., London, UK.

Pruyn, M.L., B.J. Ewers III, and F.W. Telewski. 2000. Thigmomorphogenesis: Changes in the morphology and mechanical properties of two Populus hybrids in response to mechanical perturbation. Tree Physiology 20:535-540.

Shigo, A.L. 1991. Modern Arboriculture. Shigo and Trees Associates, Durham, New Hampshire, U.S.

Slater, D., and A.R. Ennos. 2013. Determining the mechanical properties of hazel forks by testing their component parts. Trees: Structure and Function 27(6):1515-1524.

Slater, D., and A.R. Ennos. 2015. The level of occlusion of included bark affects the strength of bifurcations in hazel (Corylus avellana L.). Arboriculture \& Urban Forestry 41(4):194-207.

Slater, D., R.S. Bradley, P.J. Withers, and A.R. Ennos. 2014. The anatomy and grain pattern in forks of hazel (Corylus avellana L.) and other tree species. Trees: Structure and Function 28(5):1437-1448.

Smiley, E.T., C.M. Greco, and J.G. Williams. 2000. Brace rods for co-dominant stems: Installation location and breaking strength. Journal of Arboriculture 26:170-176.

Steucek, G.L., and R.M. Kellogg. 1972. The influence of a stem discontinuity on xylem development in Norway spruce (Picea abies). Canadian Journal of Forest Research 2:217-222.

Telewski, F.W. 2006. A unified hypothesis of mechanoperception in plants. American Journal of Botany 93:1466-76.

Telewski, F.W. 2012. Is windswept tree growth negative thigmotropism? Plant Science 184:20-28.

Vincent, J. 2012. Structural Biomaterials, third edition, Princeton University Press, New Jersey, U.S.

Whitehead, F.H. 1963. Experimental studies of the effect of wind on plant growth and anatomy. New Phytologist 62:80-85.

\author{
Duncan Slater (corresponding author) \\ Senior Lecturer of Arboriculture \\ Myerscough College \\ St. Michael's Road \\ Bilsborrow, Preston, England PR3 ORY \\ dslater@myerscough.ac.uk \\ phone: +44 1995642304 \\ A. Roland Ennos \\ Professor \\ School of Biological, Biomedical, and Environmental Sciences \\ University of Hull \\ Cottingham Road \\ Kingston-upon-Hull, England HU6 7RX
}


Résumé. La capacité des arbres à réorganiser leur structure ligneuse après une blessure ou un stress aux tissus externes contribue grandement à leur survie; cependant, ce processus de réorganisation est complexe car il est influencé par de nombreux facteurs. La rapidité et l'ampleur de la réorganisation des embranchements dans les arbres affectés par un défaut mécanique, tel que l'écorce incluse, dicteront dans quelle mesure et pendant combien de temps l'embranchement sera mécaniquement affaibli.

Pour cette étude, 100 embranchements normalement constitués sur des noisetiers communs semi-matures (Corylus avellana L.) ont été artificiellement modifiés par la pose d'haubans rigides, par des forages dans la tige centrale ou fendus, puis laissés à eux mêmes in situ, poursuivant leur croissance. Deux autres groupes ont été identifiés en tant que témoins : 120 embranchements normalement constitués et 70 embranchements présentant de l'écorce incluse. Après deux à quatre ans, ces embranchements ont été sectionnés et soumis à des tests de résistance à la flexion. Après trois saisons de croissance, les embranchements haubanés avec des tiges rigides avaient développé un défilement plus faible de leurs branches et montraient une résistance à la flexion de seulement 70,5\% par rapport à celle des embranchements normalement constitués. Les embranchements où $20 \%$ du xylème central avait été enlevé par forage étaient capables de se remettre complètement de cette anomalie; à l'inverse, les embranchements fendus ont été jugés très vulnérables aux bris lors de conditions climatiques très venteuses.

Cette étude conclut qu'un embranchement peut être considéré comme affaibli dans sa résistance à la flexion si sa tige centrale est endommagée, mais que les embranchements semi-matures chez le noisetier témoignent d'une bonne capacité à se réorganiser après une blessure. Le rôle de la thigmomorphogenèse dans ce processus de réorganisation est estimé en référence aux spécimens qui ont été haubanés et qui nont subi aucune perturbation mécanique significative de leurs tiges apicales.

Zusammenfassung. Die Fähigkeit von Bäumen, ihre Holzstruktur nach Verletzungen oder Belastungen der äußeren Gewebe neu zu strukturieren, unterstützt sie beim Überleben. Dieser Neustrukturierungsprozeß ist komplex, weil er von vielen Faktoren beeinflusst wird. Die Geschwindigkeit und das Ausmaß des Neustrukturierungsprozeßes von Astgabeln in Bäumen um eine mechanische Störung, wie zum Beispiel eingewachsene Rinde, zeigen bis zu welchem Ausmaß und für wie lang die Vergabelung mechanisch geschwächt ist.

In dieser Studie wurden 100 normal geformte Zwiesel bei noch nicht ausgewachsenen Haselnusssträuchern künstlich verändert, indem sie verdrahtet, durchgebohrt oder gespalten wurden und anschließend in situ wachsen gelassen. Zwei weitere Gruppen wurden als Kontrolle bestimmt: 120 normal geformte Zwiesel und 70 Zwiesel mit eingewachsener Rinde. Nach zwei bis vier Jahren wurden diese Zwiesel geerntet und verschiedenen Versuchen zur Biegestärke unterzogen. Die Zwiesel, die über drei Vegetationsperioden eng verdrahtet waren entwickelten zusätzliche Verjüngungen an ihren Ästen und hatten nur 70,5\% Biegestärke wie die normal geformten Zwiesel. Zwiesel mit ausgebohrten $20 \%$ ihres zentralen Zylems waren in der Lage, sich vollständig von diesem Defekt zu erholen. Im Kontrast dazu waren gespaltene Zwiesel hoch anfällig für Versagen durch Windeinwirkung.

Diese Studie ergab, dass eine Verzwieselung als ein Kompromiss in seiner Biegestärke angesehen werden kann, wenn der Scheitelpunkt ausgewogen ist. Aber halbreife Verzwieselungen bei Hasel zeigen eine gute Fähigkeit, sich nach Verletzungen wieder zu stabilisieren. Die Rolle von Thigmomorphogenesis in diesem Neustrukturierungsprozeß wird mit Referenz zu verdrahteten Verzwieselungen, die keine signifikanten mechanischen Störungen an ihrem Scheitelpunkt ausweisen, untersucht.

Resumen. La capacidad de los árboles para remodelar su estructura leñosa después de una lesión o tensión a los tejidos exteriores ayuda enormemente a su supervivencia; sin embargo, este proceso de remodelación es complejo, ya que está influenciado por muchos factores. La velocidad y el alcance de la remodelación de los empalmes de unión en los árboles alrededor de una falla mecánica, tales como corteza incluida, dictarán en qué medida y por cuánto tiempo esa unión es debilitada.

En este estudio, 100 bifurcaciones normalmente formadas en árboles semi-maduros de avellana (Corylus avellana L.) fueron modificadas artificialmente con varillas, perforadas en las bifurcaciones y luego dejadas crecer in situ. Dos grupos adicionales fueron identificados como controles: 120 bifurcaciones normalmente formadas y 70 bifurcaciones de corteza incluida. Después de dos a cuatro años, estas bifurcaciones se cosecharon y se sometieron a pruebas de su resistencia a la flexión. Las bifurcaciones rígidamente abrazadas más de tres estaciones de crecimiento desarrollados ahusamiento adverso en sus ramas y sólo tenía el 70.5\% de la resistencia a la flexión que las bifurcaciones normalmente formadas. Las bifurcaciones con el $20 \%$ del xilema central perforado fueron capaces de recuperarse completamente de este defecto; por el contrario, se encontraron bifurcaciones abiertas que fueron vulnerables a la falla durante los eventos de carga de viento.

Este estudio concluye que una bifurcación puede ser considerada un compromiso en su resistencia a la flexión si se ve afectada en su unión, pero que las bifurcaciones de árboles semi-maduros de avellana sí muestran una buena capacidad de remodelarse después de la lesión. El papel de morfogénesis en este proceso de remodelación se evalúa con referencia a los especímenes reforzados con varilla que no sufrieron ninguna perturbación mecánica significativa en sus uniones. 